\title{
Zulliger R-Optimized Application in Children Victims of Sexual Violence and Cancer
}

\author{
Eduardo dos Santos de Lima ${ }^{1}$ \\ Silvana Alba Scortegagna ${ }^{1}$ \\ Ana Carolina Bertoletti De Marchi ${ }^{1}$
}

\begin{abstract}
Child sexual violence can cause serious damage to the psychosocial development of its victims. Assessments in this context require the use of several psychological tests with proven validity for this purpose. This study aimed to assess children victims of sexual violence using the Zulliger R-Optimized application. The sample consisted of 37 children of both sexes, aged from seven to 13 years old $(M=10.92)$, distributed in three groups: Sexual Violence Victims (SVV), Cancer Patients (CP) and the Non-Victim Group (NVG). The statistical analyses were performed using the Mann-Whiney and one-way ANOVA tests. The Zulliger variables concerning the clusters Interpersonal Relationship (GHR, PHR, GHR:PHR, p), Self-Image (MOR) and Processing (W:M) showed statistical differences when the SVV group was compared to the other groups. The Zulliger R-Optimized application shows promising results in assessing SVV children, indicating its usefulness for assessments in this context.
\end{abstract}

Keywords: psychological assessment, child abuse, projective techniques, perceptual distortion, cancer in children

\section{Zulliger Aplicação R-Otimizada em Crianças Vítimas de Violência Sexual e com Câncer}

\begin{abstract}
Resumo: A violência sexual infantil pode gerar graves prejuízos para o desenvolvimento psicossocial de suas vítimas. As avaliações nesse contexto requerem o uso de vários testes psicológicos que possuem evidências de validade para este fim. Este estudo teve como objetivo avaliar crianças vítimas de violência sexual com o Zulliger aplicação R-Otimizada. A amostra consistiu em $37 \mathrm{crianças} \mathrm{com}$ idade entre 7 e 13 anos $(M=10,92)$, de ambos os sexos, distribuídas em três grupos: Vítimas de Violência Sexual (VVS), Pacientes com Câncer (PC) e Grupo de Não-Vítimas (GNV). Realizou-se tratamento estatístico por meio dos testes Mann-Whiney e Anova de uma via. Variáveis do Zulliger concernentes aos agrupamentos de Relacionamento Interpessoal (GHR, PHR, GHR:PHR, p), Autoimagem (MOR) e Processamento (W:M) apresentaram diferenças estatísticas quando o grupo VVS foi comparado aos outros grupos. O Zulliger aplicação R-Otimizada apresenta resultados promissores na avaliação de crianças VVS, indicando sua utilidade em avaliações desse contexto.
\end{abstract}

Palavras-chave: avaliação psicológica, abuso da criança, técnicas projetivas, distorção perceptiva, câncer em crianças

\section{Aplicación R-Optimizada de Zulliger en Niños Víctimas de Violencia Sexual y Cáncer}

\begin{abstract}
Resumen: La violencia sexual infantil puede causar daños al desarrollo psicosocial de las víctimas. Evaluaciones en este contexto requieren uso de exámenes psicológicos que tienen evidencia de validez para este propósito. Este estudio tuvo como objetivo evaluar niños víctimas de violencia sexual con lo Zulliger aplicación R-Optimizada. La muestra consistió en 37 niños de 7 a 13 años $(M=10.92)$, ambos sexos, distribuidos en tres grupos: Víctimas de Violencia Sexual (VVS), Pacientes con Cáncer (PC) y Grupo de No-Víctimas (GNV). El tratamiento estadístico se realizó utilizando las pruebas de Mann-Whiney y Anova de una vía. Variables de Zulliger para las agrupaciones de Relaciones Interpersonales (GHR, PHR, GHR:PHR, p), Autoimagen (MOR) y Procesamiento (W:M) mostraron diferencias estadísticas cuando el grupo VVS se comparó con los otros grupos. Zulliger aplicación R-Optimizada muestra resultados prometedores en la evaluación de niños VVS que indican su usabilidad en las evaluaciones en este contexto.
\end{abstract}

Palabras clave: evaluación psicológica, abuso de niños, técnicas proyectivas, distorción perceptiva, cáncer en niños

${ }^{1}$ Universidade de Passo Fundo, Passo Fundo-RS, Brazil

Article originated from the first author's master's dissertation under supervision by the second author, defended in 2020 in the Graduate Program in Human Aging of Universidade de Passo Fundo. Support: This study was conducted with support from Coordenação de Aperfeiçoamento de Pessoal de Nível Superior - Brazil (CAPES) - Funding Code 001.

Correspondence address: Eduardo dos Santos de Lima. Universidade de Passo Fundo. BR 285, São José, Passo Fundo-RS, Brazil. CEP 99.052-900. E-mail: eduardo_sevn@hotmail.com
Sexual violence against children is a serious public health problem. Its negative effects in the short, medium, and long term affect the healthy development of victims and burden the health care and judicial systems, requiring extensive research on intervention and treatment. This specific type of violence can be understood as all sexual interactions with a child based on power asymmetry (Ministério da Saúde, 2018). In such a relationship, an adult or an adolescent uses the child as an object to 
obtain sexual pleasure through the use of physical force, threats, coercion, and emotional manipulation.

As a result of the violence suffered, it is common to observe harmful effects on the mental health of sexual violence victims (SVV), such as interpersonal relationship difficulties (Santos, Mascarenhas, Malta, Lima, \& Silva, 2019; Schaefer, Brunnet, Lobo, Carvalho, \& Kristensen, 2018); post-traumatic stress, dysfunctional and self-destructive behavior, sexual disorders, and somatic changes (Briere, Runtz, Eadie, Bigras, \& Godbout, 2017); depressive episodes; automatic and dysfunctional thoughts, and cognitive processing problems (Gabatz, Schwartz, Milbrath, Zilmer, \& Neves, 2017; Wu, Chi, Lin, \& Du, 2018).

The hindering of thinking stems precisely from the child's inability to bear the perception of his or her harsh reality and the suffering resulting from it (Scortegagna \& Villemor-Amaral, 2012). The authors report that the ability to think, investigate and symbolize becomes precarious and the processes of understanding and adjusting to the world become impaired, although the damage to the development of thought and learning is not commonly related to a deficiency in cognitive structures, but to a symptomatic inhibition as an attempt to remove a dangerous situation that generates anxiety for the ego, which is knowing one's own story. Thus, not everything may be available at the symbolic level of the word, and when the time of what cannot be revealed is not respected because there is no possibility of psychic elaboration, what may occur is revictimization.

It is in this traumatic context that psychological evaluations with projective techniques can benefit the investigation process both to help identify cases of sexual violence suffered and to guide specific interventions for these children. Given the validity evidence, the indirect access to understanding psychological functioning can be of great importance by providing the necessary information to understand the personality characteristics and emotional dynamics of children who have been subjected to sexual violence, bringing greater security and technical and scientific support to evaluators and in legal decision making (Scortegagna \& Villemor-Amaral, 2012).

Among the instruments available, the Rorschach Method showed validity evidence in assessing sexual violence victims (De Michèle et al., 2019; Scortegagna, Ribeiro, \& Villemor-Amaral, 2016; Scortegagna \& Villemor-Amaral, 2012, 2013) as well as similarities to the Zulliger Method (Biasi \& Villemor-Amaral, 2016; Cardoso, Gomes, \& Vieira, 2018). Both tests shared the Comprehensive System (CS), in which inkblot cards are presented to the assessed subjects and they must answer the question "what does this look like?" or "what could this be?" After being transcribed verbatim, the answers are coded to form the structural summary, and the results are quantitatively and qualitatively interpreted (Exner, 1999; Villemor-Amaral \& Primi, 2009).

When compared to other systems, the Rorschach Method in the Comprehensive System (Exner, 1999) has recently shown results with greater statistical support and the advantage of normative data on international databases (Lewey, Kivisalu, \& Giromini, 2019), when using the Performance Assessment System - R-PAS (Meyer, Viglione, Mihura, Erard, \& Erdberg, 2017). In line with these advances, the Zulliger Method in the Comprehensive System (ZCS) has been studied with the orientation of controlling the number of answers (Seitl et al., 2018), as used in R-PAS. This orientation consists in asking the individual assessed by Zulliger to issue from three to five answers on each card during the application.

Although these advances provide greater statistical quality and support to psychologists who work with these two tools, there are few studies in Brazil that use the ZCS for evaluations in crime situations. This scenario is worrisome especially in assessments of children who have been victims of sexual violence. One of the reasons is that victims do not always display visible physical marks of the violence suffered, mainly due to the influence that the abuser can exert on the child's loyalty and trust, so that physical violence is not always used to commit sexual violence (Scortegagna \& VillemorAmaral 2012), as happens in various forms of harassment, exhibitionism or voyeurism (Habigzang \& Koller, 2011). In this scenario, investigating the psychic marks resulting from sexual violence becomes essential in an evaluative process.

Considering the small number of three ZCS plates in relation to the 10 plates of the Rorschach method, ZCS could track the psychic marks of childhood sexual violence in a shorter application time, serving as an instrument option in assessment processes, besides being able to reduce the time and costs of such processes. However, in the last 10 years, only four studies have sought validity evidence for ZCS with children, and none have used the adaptation to this date to control the number of answers with children who have been victims of sexual violence, which reinforces the need for further research.

Among the studies that sought validity evidence of ZCS use for children, we highlight those showing that the test was able to distinguish children's performance in evolutionary terms across different ages (Cardoso et al., 2018), to differentiate socially popular children from less popular children based on indicators associated with better quality in interpersonal relationships (Biasi \& Villemor-Amaral, 2016), and to understand how children develop maturity for interpersonal relationships (Villemor-Amaral \& Vieira, 2016). Finally, it showed that it is possible to distinguish emotional, social, and cognitive aspects of child development that are typical of different age groups from six to 12 years old (Villemor-Amaral, Pavan, Tavella, Cardoso, \& Biasi, 2016).

Another important factor that proposes the need for studies on ZCS in assessing children in a context of vulnerability are the similarities of experiences in other traumatic situations, which could generate similar answers in ZCS. This is the case of patients with cancer or other bodily illnesses, where interpersonal relationships may also be affected. The study by Anthony et al. (2019) assessing 37 children and adolescents who were cancer patients identified significant social impairment due to the side effects of cancer and withdrawal from school. The presence of feelings of isolation and distress was also identified in addition to the physical effects of the disease.

Associated with social harm, the physical trauma caused by cancer can generate psychological effects that are similar to those caused by sexual violence. Cancer can elicit feelings of body annihilation, body incongruity, and damage to self-image (Signorelli, 2015), and chronic pain can generate negative views of self, as well as social isolation can foster pain perception and increased concern about one's own body (Balottin et al., 2018; Yamamoto et al., 2010). Both childhood sexual violence and cancer do occur in the physical body, but it is in the psychological realm that anguish and emotional suffering manifest.

Results from the assessment of children who have been SVV and patients with cancer and other bodily illnesses have 
shown some of these similarities. SVV children assessed by the Rorschach Method (Barnett, Heinze, \& Arble, 2013; Perfect, Tharinger, Keith, \& Lyle-Lahroud, 2011; Scortegagna \& Villemor-Amaral, 2013) showed self-perception problems (MOR) interpersonal relationship difficulties (PER, PHR, T, AG), affective interaction difficulties (SumC', SumY') and perceptual adjustment problems (FQ-). Other studies conducted on patients with cancer and other bodily diseases (Balottin et al., 2018; Signorelli, 2015; Yamamoto et al., 2010) also showed self-perception problems (MOR), interpersonal relationship difficulties (PER, PHR, T, AG), difficulties in affective interactions (SumC', SumY), and perceptual adjustment problems (FQ-).

There is a lack of studies that seek to evaluate children with cancer using projective methods such as Zulliger or Rorschach. To the best of our knowledge, only one study on 18 children, who were cancer patients, used the Rorschach Method (Goggin, Lansky, \& Hassanein, 1976). The results showed a high level of anxiety in younger boys and older girls, and older girls showed greater distortion in world perception.

Social impairment, changes in self-image, and feelings of distress and anxiety may be experienced by both SVV children and children undergoing cancer treatment. Thus, discriminating indicators of SVV children in ZCS may also be representative of the suffering of people who have not experienced sexual violence, but have been victimized by experiences of illnesses that can be traumatic, such as cancer. These similarities exclaim the need for studies that use ZCS and that simultaneously evaluate these two groups seeking to identify the variables that differentiate the group of SVV children.

Furthermore, the lack of studies using ZCS both for children who have suffered sexual violence and children with cancer is noteworthy, which has encouraged the development of this study in order to understand the specificities of the answers from each group to the instrument, which could benefit psychological assessments in these contexts. Thus, in line with the advances in the studies on ZCS and the need for studies on this tool in children's assessment, this study aimed to evaluate children who have been victims of sexual violence by using the Zulliger R-Optimized application.

\section{Method}

\section{Participants}

In this preliminary study, the initial sample consisted of 37 children aged seven to 13 years old $(M=10.92, S D=1.785)$, both male $(n=19)$ and female $(n=18)$, distributed into three groups: the Sexual Violence Victim (SVV) Group, the Cancer Patient (CP) Group, and the Non-Victim Group (NVG).

The SVV group consisted of 14 children from institutions connected to municipal governments that serve children victims of all types of violence, whose objective is to develop protection and prevention actions against child and adolescent sexual violence. As an inclusion criterion for this group, the children should have a history of documented sexual violence. Such a record consisted of an official document attesting to sexual violence indicators which is used by prosecutors/judges in cases against the suspected abuser. As an exclusion criterion, the children could not have a history of cancer or similar illness or unconfirmed suspicion of sexual violence. This group consisted of six male and nine female children, with a mean age of 11.07 years $(S D=1.94)$; five children were from seven to ten years old. The average education found was 4.93 years of schooling $(S D=1.58)$.

The PC group comprised ten children. This group consisted of children undergoing treatment for cancer in a referral hospital for children's oncology in the region. The inclusion criterion for this group was that the children should have a medical diagnosis of the disease. As an exclusion criterion, the children could not have a history or suspicion of sexual violence. This group consisted of six male and four female children with a mean age of 11 years $(S D=1.41)$; three children were from seven to ten years old. The average education found was 5.33 years of schooling $(S D=1.41)$.

The NVG group consisted of 13 children with no history of sexual violence and/or cancer. This group included children who regularly attended public schools. As an inclusion criterion, the children should not have a history or suspicion of sexual violence, and should not be under treatment for cancer or any chronic diseases. This group consisted of seven male and six female children, with a mean age of 10.62 years $(S D$ $=1.93$ ). Four of the children were from seven to 10 years old. The average schooling found was 5.08 years $(S D=1.70)$.

\section{Instruments}

Zulliger Comprehensive System (ZCS) (VillemorAmaral \& Primi, 2009). Technique applied to obtain information on mental functioning. It consists of three plates with inkblots on which the subject must answer the question: "what does this look like?". In this study, the recommendation followed in R-PAS (Meyer et al., 2017) was used by changing the test instruction. In order to increase and control the number of answers, a minimum of three and a maximum of five answers on each card were requested. In this study, the variables comprising the Interpersonal Relationship, Processing, and Self-Image clusters described in the Structural Summary were considered for analysis $(n=26)$. The correction followed the Comprehensive System instructions.

Personality Trait Scale for Children (ETPC) (Sisto, 2004) (from five to ten years old), Personality Scale for Children and Adolescents (EPQ-J) (Eysenck \& Eysenck, 2013) (from ten to 16 years old). In common, the instruments assess personality traits, such as Extroversion, Neuroticism, and Psychoticism. ETPC specifically assesses Sociability, and EPQ-J assesses Sincerity. ETPC has good internal consistency indices (Cronbach's alpha) and a four-component factor structure: Extroversion $(\alpha=0.88)$, Neuroticism $(\alpha=0.80)$, Psychoticism $(\alpha=0.91)$, and Sociability $(\alpha=0.88)$. EPQ-J also shows good internal consistency indices (Cronbach's alpha) and a four-component factor structure: Extroversion $(\alpha$ $=0.69)$, Neuroticism $(\alpha=0.79)$, Psychoticism $(\alpha=0.75)$, and Sincerity $(\alpha=0.79)$. Each child answered the age-appropriate instrument. Those aged from seven to ten years answered ETPC, and those aged from 11 to 13 years answered EPQ-J.

Inventory of Social Skills (IHS), Behavior Problems and Academic Competence for Children (SSRS) (Del Prette, 2017). It assesses social skills in children aged from six to 13 years old, describes the overall score (OS), empathy/affectivity (F1), responsibility (F2), self-control/ civility (F3), and assertiveness (F4). It has reasonable internal consistency indices (Cronbach's alpha) and a five- 
component factor structure: OS $(\alpha=0.73), \mathrm{F} 1(\alpha=0.63)$, F2 $(\alpha=0,60), \mathrm{F} 3,(\alpha=0.54)$ and F4, $(\alpha=0.41)$.

\section{Procedures}

Data collection. After contacting the institutions, a survey was conducted of the children who met the inclusion criteria for participation in the study. Next, the children's parents or legal guardians were contacted in person at the institutions and informed about the study objectives and procedures. Upon signature of the Informed Consent Form by the parents or legal guardians, the children were contacted in person and invited to participate in the study and those who accepted the invitation were asked to sign the Informed Consent Form. Data were collected individually, on the institutions' premises, in a room specially designed for the application without external interference, in an attempt to maintain the secrecy and confidentiality of the answers. The evaluations occurred in a single one-hour session after an initial rapport, which varied in length according to each child's condition. The objective of such initial bonding was to create a protective, caring, and favorable environment for test application, considering the application situations and contexts so as not to cause further damage.

Data analysis. For reliability analysis, $25 \%$ of the protocols $(n=9)$ were randomly selected and corrected by an independent judge, an expert in the Zulliger method. The variables composing the Interpersonal Relationship, Processing, and Self-Image clusters were evaluated by the Intraclass Correlation Coefficient (ICC), a two-factor mixed model, seeking absolute agreement with a $95 \%$ confidence interval. The interpretation of results followed the recommendations by Cicchetti (1994), considering excellent results as ICC values $\geq 0.75$, good results as $0.6 \leq \mathrm{ICC}<0.75$, reasonable results as $0.4 \leq \mathrm{ICC}<0.6$, and poor results as ICC $<0.4$. For statistical analysis, Mann-Whiney and oneway Anova tests were used, considering $p<0.05$. The choice of statistical tests was based on the number of subjects in each group, and the requirements for comparison between the three groups.

\section{Ethical Considerations}

All procedures were approved by the Research Ethics Committee of Universidade de Passo Fundo (CAAE no. 18637719.5.0000.5342, Report no. 3.622.765/2019).

\section{Results}

The reliability analysis of the protocols was initially performed using ICC. Table 1 shows the data found.

The ICC values for the ZCS variables mostly showed excellent $(n=19,70 \%)$ and good $(n=2,7.4 \%)$ results. The other variables $(n=6,22 \%)$ showed zero values for the protocols drawn, reinforcing the evaluators' agreement in not assigning these codes to the answers found in these protocols.

In order to compare and identify variables showing statistical differences, we first performed the Mann-Whiney test between SVV and NVG and between PC and NVG. Table 2 shows the results for the variables that integrate the ZCS Interpersonal Relationship, Processing, and Self-image indices, and the variables for the Personality (ETPC, EPQ-J) and Social Skills (SSRS) instruments.
Table 1

Intraclass Correlation Coefficient for the ZCS Variables

\begin{tabular}{|c|c|c|}
\hline Variable & $\begin{array}{c}\text { Intraclass Correlation } \\
\text { Coefficient }\end{array}$ & Classification \\
\hline \multicolumn{3}{|l|}{$\begin{array}{l}\text { Interpersonal } \\
\text { relationships }\end{array}$} \\
\hline $\mathrm{COP}$ & 0.722 & Excellent \\
\hline $\mathrm{AG}$ & 0.919 & Excellent \\
\hline GHR & 0.818 & Excellent \\
\hline PHR & 0.967 & Excellent \\
\hline GHR:PHR & 0.935 & Excellent \\
\hline $\mathrm{a}$ & 0.969 & Excellent \\
\hline $\mathrm{p}$ & 0.718 & Good \\
\hline$a: p$ & 0.764 & Excellent \\
\hline $\mathrm{Fd}$ & $*$ & $*$ \\
\hline SumT & $*$ & $*$ \\
\hline SumH & 0.987 & Excellent \\
\hline PureH & 0.983 & Excellent \\
\hline PER & 0.980 & Excellent \\
\hline Isolation & 0.980 & Excellent \\
\hline \multicolumn{3}{|l|}{ Processing } \\
\hline $\mathrm{Zf}$ & 0.637 & Good \\
\hline W:D:Dd & 0.756 & Excellent \\
\hline W:M & 0.981 & Excellent \\
\hline PSV & * & * \\
\hline $\mathrm{DQ}^{+}$ & 0.973 & Excellent \\
\hline DQv & 0.796 & Excellent \\
\hline \multicolumn{3}{|l|}{ Self-image } \\
\hline $3 r+(2)$ & 0.940 & Excellent \\
\hline $\mathrm{Fr}+\mathrm{rF}$ & * & $*$ \\
\hline SumV & $*$ & $*$ \\
\hline$A n+X y$ & 0.846 & Excellent \\
\hline MOR & 0.947 & Excellent \\
\hline $\mathrm{H}:(\mathrm{H})+\mathrm{Hd}+(\mathrm{Hd})$ & 0.990 & Excellent \\
\hline
\end{tabular}

Note. ${ }^{*}$ The protocols drawn did not have answers on these variables. $3 r+(2)=$ Sum of answers with reflex and pair; a:p= Ratio between answers with active and passive movement; $\mathrm{AG}=$ Aggressive movement; $\mathrm{An}+\mathrm{Xy}=$ Sum of anatomy and $\mathrm{x}$-ray content; COP $=$ Cooperative Movement; $\mathrm{DQ}+=$ Development Quality; $\mathrm{DQv}=$ Vague development quality; $\mathrm{Fd}=$ Food content; $\mathrm{Fr}+\mathrm{rF}=$ Sum of reflex contents; GHR:PHR = Ratio between good and bad human representation answers; $\mathrm{H}:(\mathrm{H})+\mathrm{Hd}+(\mathrm{Hd})=$ Ratio between whole human content answers and human and para-human details; MOR = Morbid content; PER $=$ Personalized content; PSV $=$ Content with perseverance; PureH $=$ Answers with whole human content; SumH = Sum of human content answers; SumT = Sum of textured answers; SumV = Sum of answers with a view; W:D:Dd = Ratio between global answer, detail and unusual detail; $\mathrm{W}: \mathrm{M}=$ Ratio between global answer and human movement; $\mathrm{Zf}=$ Frequency of Z-scores.

As shown in Table 2, of the 26 variables that integrate the ZCS clusters analyzed, 10 showed statistical differences when comparing SVV with NVG. Besides these, variables Psychoticism and Sincerity of the Personality instruments 
and variable GS of SSRS also showed statistical differences. No variables showed statistically significant differences when comparing CP and NVG. Next, the one-way Anova test was performed, comparing the three groups (SVV, CP, and NVG) simultaneously. The results are shown in Table 3.

Table 3 demonstrates that, of the variables showing statistical difference by the Mann-Whitney test, only six ZCS variables, the Psychoticism variable of the Personality tests, and the GS variable of SSRS maintained statistically significant differences when comparing SVV and the other groups through the analysis by the one-way ANOVA test. Other variables also showed statistically significant difference, but since they did not obtain the same result in the first test, they were not considered for analysis.

Also, after identifying the variables showing statistical differences in the group of SVV children, it is necessary to identify how such a difference arose. The group of SVV children showed significant increase for the PHR variables, and in the PHR ratio in GHR:PHR, (p), MOR, in the M ratio in W:M, and in the Psychoticism variable of the ETPC and EPQ-J tests. On the other hand, there was significant decrease in the GHR variables and the GS variable of SSRS.

Table 2

Comparison of the SVV and CP Groups with the NVG Group

\begin{tabular}{|c|c|c|c|c|c|c|}
\hline & $\begin{array}{l}\text { Mann-Whiney } \\
\text { (SVV-NVG) }\end{array}$ & $p$ & $U$ & $\begin{array}{c}\text { Mann-Whiney (CC- } \\
\text { NVG) }\end{array}$ & $p$ & $U$ \\
\hline \multicolumn{7}{|l|}{ Relationships } \\
\hline $\mathrm{COP}$ & & 1.000 & 91.000 & & 0.541 & 57.000 \\
\hline $\mathrm{AG}$ & & 0.551 & 79.500 & & 0.357 & 52.000 \\
\hline GHR & & 0.037 * & 50.000 & & 0.413 & 52.500 \\
\hline PHR & & $0.005 *$ & 34.500 & & 0.948 & 64.000 \\
\hline GHR:PHR & & $0.014 *$ & 46.000 & & 0.677 & 59.000 \\
\hline $\mathrm{a}$ & & 0.784 & 85.500 & & 0.501 & 54.500 \\
\hline $\mathrm{p}$ & & 0.010 * & 40.500 & & 0.569 & 56.500 \\
\hline$a: p$ & & 0.242 & 68.500 & & 0.587 & 57.000 \\
\hline $\mathrm{Fd}$ & & 0.165 & 78.000 & & 0.254 & 58.500 \\
\hline SumT & & 0.215 & 71.500 & & 0.195 & 49.000 \\
\hline SumH & & 0.186 & 64.500 & & 0.309 & 49.000 \\
\hline PureH & & 0.318 & 71.000 & & 0.846 & 62.000 \\
\hline PER & & 0.553 & 80.000 & & 0.770 & 61.000 \\
\hline Isolation & & 0.783 & 85.500 & & 0.459 & 53.500 \\
\hline \multicolumn{7}{|l|}{ Processing } \\
\hline $\mathrm{Zf}$ & & 0.297 & 70.000 & & 0.091 & 38.500 \\
\hline W:D:Dd & & 0.356 & 73.500 & & 0.138 & 42.000 \\
\hline W:M & & 0.011* & 42.500 & & 0.145 & 44.000 \\
\hline PSV & & 0.564 & 83.000 & & 0.422 & 56.500 \\
\hline $\mathrm{DQ}^{+}$ & & 0.400 & 74.000 & & 0.659 & 58.000 \\
\hline DQv & & 0.717 & 84.000 & & 0.236 & 47.500 \\
\hline \multicolumn{7}{|l|}{ Self-image } \\
\hline $3 r+(2) / R$ & & 0.166 & 63.000 & & 0.899 & 63.000 \\
\hline $\mathrm{Fr}+\mathrm{rF}$ & & 1.000 & 91.000 & & 1.000 & 65.000 \\
\hline SumV & & 0.335 & 84.500 & & 0.254 & 58.500 \\
\hline $\mathrm{Fd}$ & & 0.165 & 78.000 & & 0.254 & 58.500 \\
\hline $\mathrm{An}+\mathrm{Xy}$ & & 0.652 & 83.000 & & 0.680 & 59.000 \\
\hline MOR & & $0.007 *$ & 38.000 & & 0.659 & 59.000 \\
\hline $\mathrm{H}:(\mathrm{H})+\mathrm{Hd}+(\mathrm{Hd})$ & & $0.043 *$ & 53.500 & & 0.498 & 55.500 \\
\hline \multicolumn{7}{|l|}{ Personality } \\
\hline Psychoticism & & 0.003* & 31.000 & & 0.975 & 64.500 \\
\hline Extroversion & & 1.000 & 91.000 & & 0.118 & 40.500 \\
\hline Neuroticism & & 0.446 & 75.500 & & 0.070 & 36.000 \\
\hline Sociability & & 0.563 & 9.500 & & 0.149 & 4.000 \\
\hline Sincerity & & $0.049 *$ & 15.000 & & 0.795 & 22.500 \\
\hline \multicolumn{7}{|l|}{ Social Skills } \\
\hline GS & & $0.036 *$ & 48.000 & & 0.732 & 59.500 \\
\hline F1 & & 0.178 & 63.500 & & 0.179 & 43.500 \\
\hline F2 & & 0.078 & 55.000 & & 0.056 & 34.500 \\
\hline F3 & & 0.087 & 56.000 & & 0.950 & 64.000 \\
\hline F4 & & 0.660 & 82.000 & & 0.135 & 41.000 \\
\hline
\end{tabular}

Note. ${ }^{*} p<0.01$; ZCS codes $=$ The same as those for Table 1; GS = General Score; F1 = empathy/affectivity; F2 = Responsibility; F3 = Self-control/ civility; F4 = Assertiveness. 
Table 3

Simultaneous Comparison between the SVV, CP and NVG Groups

\begin{tabular}{|c|c|c|c|c|c|}
\hline \multirow[t]{2}{*}{ Variable } & \multicolumn{3}{|c|}{ Mean $(S D)$} & \multirow[t]{2}{*}{$F$} & \multirow[t]{2}{*}{$p$} \\
\hline & SVV & $\mathrm{CP}$ & NVG & & \\
\hline \multicolumn{6}{|l|}{ Relationships } \\
\hline $\mathrm{COP}$ & $0.50(0.76)$ & $0.40(0.84)$ & $0.46(0.66)$ & 0.052 & 0.949 \\
\hline $\mathrm{AG}$ & $1.36(1.90)$ & $0.40(0.69)$ & $0.92(1.32)$ & 1.255 & 0.298 \\
\hline GHR & $0.71(0.91)$ & $1.90(0.99)$ & $1.62(1.32)$ & 3.996 & $0.028 *$ \\
\hline PHR & $3.21(1.96)$ & $0.90(0.87)$ & $1.08(1.25)$ & 9.561 & 0.001* \\
\hline GHR:PHR & $2.64(0.74)$ & $1.60(0.84)$ & $1.76(0.92)$ & 5.664 & 0.008* \\
\hline $\mathrm{a}$ & $1.93(1.68)$ & $1.60(1.83)$ & $2.00(2.04)$ & 0.144 & 0.866 \\
\hline $\mathrm{p}$ & $2.00(1.46)$ & $1.00(1.05)$ & $0.69(0.63)$ & 4.980 & 0.013* \\
\hline $\mathrm{a}: \mathrm{p}$ & $2.00(0.87)$ & $1.80(0.78)$ & $1.61(0.65)$ & 0.821 & 0.448 \\
\hline Food & $0.14(0.36)$ & $0.10(0.31)$ & $0.00(0.00)$ & 0.926 & 0.406 \\
\hline SumT & $0.21(0.57)$ & $0.30(0.94)$ & $0.38(0.50)$ & 0.214 & 0.808 \\
\hline SumH & $3.07(1.20)$ & $2.80(0.91)$ & $2.62(2.21)$ & 0.282 & 0.756 \\
\hline PureH & $1.29(1.20)$ & $1.80(0.79)$ & $1.85(1.40)$ & 0.901 & 0.415 \\
\hline PER & $1.29(2.12)$ & $0.60(1.07)$ & $0.92(1.93)$ & 0.416 & 0.663 \\
\hline Isolation & $1.64(1.27)$ & $1.80(1.87)$ & $1.85(1.06)$ & 0.078 & 0.925 \\
\hline \multicolumn{6}{|l|}{ Processing } \\
\hline $\mathrm{Zf}$ & $4.64(1.64)$ & $2.70(2.21)$ & $4.15(2.47)$ & 2.543 & 0.094 \\
\hline $\mathrm{W}: \mathrm{M}$ & $2.35(0.84)$ & $2.00(0.94)$ & $1.46(0.77)$ & 3.788 & 0.033* \\
\hline PSV & $0.14(0.36)$ & $0.10(0.31)$ & $0.23(0.43)$ & 0.363 & 0.698 \\
\hline $\mathrm{DQ}^{+}$ & $3.07(1.63)$ & $2.10(1.72)$ & $2.62(1.89)$ & 0.896 & 0.418 \\
\hline DQv & $0.79(0.80)$ & $0.60(1.07)$ & $1.00(1.08)$ & 0.477 & 0.625 \\
\hline \multicolumn{6}{|l|}{ Self-image } \\
\hline $3 r+(2) / R$ & $2.86(1.51)$ & $2.00(1.49)$ & $2.15(1.57)$ & 1.134 & 0.334 \\
\hline $\mathrm{Fr}+\mathrm{rF}$ & $0.00(0.00)$ & $0.00(0.00)$ & $0.00(0.00)$ & . & . \\
\hline SumV & $0.07(0.26)$ & $0.10(0.31)$ & $0.00(0.00)$ & 0.589 & 0.561 \\
\hline Food & $0.14(0.36)$ & $0.10(0.31)$ & $0.00(0.00)$ & 0.926 & 0.406 \\
\hline $\mathrm{An}+\mathrm{Xy}$ & $0.71(1.32)$ & $0.70(0.82)$ & $0.54(0.66)$ & 0.122 & 0.886 \\
\hline MOR & $1.79(1.18)$ & $0.40(0.69)$ & $0.54(0.77)$ & 8.495 & 0.001* \\
\hline $\mathrm{H}:(\mathrm{H})+\mathrm{Hd}+(\mathrm{Hd})$ & $2.21(0.97)$ & $1.60(0.69)$ & $1.46(0.77)$ & 3.035 & 0.061 \\
\hline \multicolumn{6}{|l|}{ Personality } \\
\hline Psychoticism & $61.79(27.35)$ & $28.00(23.11)$ & 28.85 (21.99) & 8.069 & 0.001* \\
\hline Extroversion & $56.07(29.10)$ & $71.50(25.06)$ & $56.92(26.50)$ & 1.119 & 0.338 \\
\hline Neuroticism & $72.43(19.08)$ & $47.00(22.75)$ & $62.31(25.21)$ & 3.768 & $0.033 *$ \\
\hline Sociability & $43.75(23.93)$ & $33.33(14.43)$ & $50.00(15.81)$ & 0.822 & 0.467 \\
\hline Sincerity & $53.50(22.85)$ & $36.43(21.74)$ & $32.86(16.03)$ & 2.450 & 0.111 \\
\hline \multicolumn{6}{|l|}{ Social Skills } \\
\hline GS & $24.86(24.83)$ & $49.00(23.54)$ & $46.38(26.83)$ & 3.541 & $0.040 *$ \\
\hline $\mathrm{F} 1$ & $31.64(33.20)$ & $57.50(23.00)$ & $43.85(25.50)$ & 2.475 & 0.099 \\
\hline $\mathrm{F} 2$ & $40.71(38.20)$ & $41.80(29.17)$ & $65.38(31.32)$ & 2.192 & 0.127 \\
\hline F3 & $45.36(32.13)$ & $64.00(25.25)$ & $63.31(27.87)$ & 1.732 & 0.192 \\
\hline $\mathrm{F} 4$ & $30.79(20.99)$ & $46.50(31.18)$ & $30.08(28.78)$ & 1.312 & 0.283 \\
\hline
\end{tabular}

Note. ${ }^{*} p<0.01$. ZCS codes $=$ The same as those for Table 1; GS = General Score; F1 = empathy/affectivity; F2 = Responsibility; F3 = Selfcontrol/ civility; F4 = Assertiveness. 


\section{Discussion}

This study identified preliminary evidence that when assessing SVV children, the ZCS R-optimized application shows indicators of sexual violence. By empirically controlling the number of answers on ZCS, it was possible to identify that variables GHR, PHR, GHR:PHR, p, MOR, and W:M showed statistical differences when the SVV group was compared to non-victim groups. When submitted to a battery of tests with different settings and group comparisons, these variables remained constant, indicating their promising statistical qualities.

In the Interpersonal Relationship cluster of ZCS, of the variables showing statistical difference (GHR, PHR, GHR:PHR and p), it is possible to observe the quality of the representation that SVV children have of themselves and other people through the increase in the mean of PHR answers and the decrease in the mean of GHR answers and the tendency to adopt more passive behaviors, as indicated by the increased answer mean (p), (VillemorAmaral \& Primi, 2009). Such results point out that social interactions may become moments of distress or fear, and reveal that the marks left by the abuse situation may remain active in these children's forms of interaction with other people. The previous literature already indicated that SVV children may have greater difficulty in interpersonal relationships (Santos et al., 2019; Schaefer et al., 2018; Scortegagna et al., 2016).

It is noticeable that SVV children showed more answers with PHR content, with a strong statistical difference $(p<0.001)$ as compared to the other groups. At the same time, these children tend to show a smaller number of GHR answers. In assessing the interpersonal relationship variables of ZCS by comparing a group of more popular children with another group of less popular children selected by their peers at school, the study by Biasi and VillemorAmaral (2016) found no significant differences between PHR and GHR:PHR variables, thus suggesting that, for ZCS, these variables may be important indicators of the effects of child sexual violence. The study by Villemor-Amaral and Vieira (2016) also corroborates this information by showing no statistical differences in PHR and GHR variables when assessing the relational maturity of children of different developmental stages (six and 12 years old), with no history of psychological or psychiatric care.

When increased in relation to the GHR variable, the PHR variable signals that the subject evaluated has negative, distorted, unrealistic, damaged or even aggressive perceptions of himself and the people around him (VillemorAmaral \& Primi, 2009). The significant increase in PHR, in this sense, shows that sexual violence can cause an important negative effect on victims' perceptions, directly affecting the quality of these children's relationships.

In addition to the impaired perception of human representations, SVV children showed a significant increase $(p<0.001)$ in the MOR variable. That variable is related to the perception of oneself and objects as damaged, which can also be understood as a devalued personal image, articulated with negative, damaged or dysphoric traits (VillemorAmaral \& Primi, 2009). These findings reaffirm previous studies conducted on SVV children assessed by the Rorschach Method, indicating the extent of the trauma suffered and its connection to an impaired self-image with strong associations with damaged, torn or fragmented bodies as results of the violence suffered (Scortegagna \& Villemor-Amaral, 2013; Scortegagna et al., 2016). Concomitant to the significant increase in variable PHR, it is observed that child sexual violence causes significant damage to the victims' mental health, causing them to perceive themselves, the objects and the people around them in a compromised way, with perceptual distortions strongly associated with negative elements.

Variable $(p)$ showed a significant increase $(p=0.013)$ in the SVV group. Such a result indicates a tendency to passive behavior although not necessarily submissive (Exner \& Sendín, 1999). Other studies in which children from normative groups were evaluated showed no increase for this variable (Cardoso et al., 2018; Villemor-Amaral \& Vieira, 2016; Villemor-Amaral et al., 2016). Although in the study by Biasi and Villemor-Amaral (2016) the authors found a significant difference in this variable in association with popular children, it was understood that these children showed more human-movement answers, which can be understood as a type-I error, where a variable shows a significant increase due to its dependency relationship to another variable that also showed a significant increase, but such increase does not represent a specific behavior of that group, but only pure mathematical compensation.

Thus, the increase in variable $(p)$, associated with other harms indicated by the increase in PHR and MOR, for the SVV group of children, may indicate increased risk for revictimization. For Exner (1999), an increase in ( $p$ ) may indicate excessive support in their environment, with the expectation that others will make their decisions. However, due to the association with other variables and the perceptual distortions, the risk for becoming involved in risky situations seems to increase.

The damage to Interpersonal Relationships indicated by the ZCS reaffirms the findings of the significant decrease in scores of variable GS of SSRS in the SVV group. When assessing children in a school, the study by CasaliRobalinho, Del Prette, and Del Prette (2015) found higher mean scores for this variable, indicating that children in normative groups tend to have a better repertoire of social skills when compared to SVV children, which can provide indicators of areas of greater damage.

Variable W:M showed a significant higher ratio of $M$ in relation to $\mathrm{W}$ in the SVV group. This ratio is associated with cautious and conservative behaviors, and indicates inhibition of productivity and a form of defense against fear of competition (Villemor-Amaral \& Primi, 2009). As compared to the other studies that assessed children in normative groups (Biasi \& Villemor-Amaral, 2016; Cardoso et al., 2018; Villemor-Amaral \& Vieira, 2016; Villemor-Amaral et al., 2016), it is observed that in none of them did that variable 
take prominence, indicating that the sexual violence factor may have been a trigger for this behavior in the SVV group of children. The greater ratio of $\mathrm{M}$ over $\mathrm{W}$ may be associated with cautious individuals who perform below their real potential (Villemor-Amaral \& Primi, 2009), which may mutually be associated with a more passive behavior (p), where perception is shown to be more distorted from reality (PHR, MOR), an effect that may be connected to child sexual violence.

Finally, there is also the complementary indicator Psychoticism, with a significant increase in the SVV group. When this ETPC and EPQ-J indicator is high, it indicates a greater propensity for cold, lonely, and antisocial behavior (Sisto, 2004), and a certain lack of concern for the feelings of others, showing a lower degree of empathy (Eysenck \& Eysenck, 2013).

This indicator complements and corroborates the findings by ZCS, showing the degree of SVV children's impairment in interpersonal relationships. In evaluating 90 school-aged children, Simões and Castro (2018) concluded that most of them showed lowered Psychoticism values in all the analyses performed. It is possible to infer that sexual violence may be an important factor in the increased Psychoticism found in this study.

While this study innovates in proposing the assessment of SVV children by ZSC, and adds important information on these children's psychological functioning, its limitations must still be taken into consideration. Given its nature, the sample size is small; therefore, statistical analyses must be carefully evaluated, even if they indicate significant differences and respect the requirements of each statistical test. However, the use of ICC, the comparison to different groups, and the methods of statistical analysis support the results and emphasize the importance of this study.

The ZCS R-Optimized application seems to show promising results in locating indicators of child sexual violence. From the statistical analyses, it was possible to map that the increase in variables PHR, MOR, $p$ and $\mathrm{W}: \mathrm{M}$, with a higher ratio of $\mathrm{M}$ over $\mathrm{W}$, remains constant when compared to different groups. The decrease in variable GHR and its ratio in GHR:PHR show to be important indicators for the SVV group and should be highlighted. Even though the SVV and CP groups may show similarities, the ZCS R-optimized application showed differences between the groups.

The analyses of the psychological tests converge to the understanding that the children in the SVV group generally show significant personality development impairments, and that they reflect in the social sphere. By demonstrating its potential to identify such impairments, the ZCS R-Optimized application may be among the choices of psychological tests in evaluations of SVV children.

Finally, considering the promising preliminary results, the importance of the projective personality assessment test, and the small number of studies on these topics, there is still the suggestion of further studies aiming at finding validity evidence for the ZSC R-Optimized application. The expansion of samples and the inclusion of other traumatic contexts, such as accidents causing bodily harm, are also suggested in order to confirm or not the importance of using the test.

\section{References}

Anthony, S. J., Robertson, T., Selkirk, E., Dix, D., Klaassen, R. J., Sung, L., ... Klassen, A. F. (2019). The social impact of early psychological maturity in adolescents with cancer. Psychooncology, 28(3), 586-592. doi:10.1002/pon.4982

Balottin, L., Mannarini, S., Candeloro, D., Mita, A., Chiappedi, M., \& Balottin, U. (2018). Rorschach evaluation of personality and emotional characteristics in adolescents with migraine versus epilepsy and controls. Frontiers in Neurology, 9, 160. doi:10.3389/ fneur.2018.00160

Barnett, D., Heinze, H. J., \& Arble, E. (2013). Risk, resilience, and the Rorschach: A longitudinal study of children who experienced sexual abuse. Journal of Personality Assessment, 95(6), 600-609. doi:10.1080/ 00223891.2013 .823437

Biasi, F. C., \& Villemor-Amaral, A. E. (2016). Evidências de validade do Zulliger-SC para avaliação do relacionamento interpessoal de crianças [Evidence of validity of Zulliger-SC to the assessment of children's interpersonal relationship]. Psico, 47(1), 13-23. doi:10.15448/ 1980-8623.2016.1.19990

Briere, J., Runtz, M., Eadie, E., Bigras, N., \& Godbout, N. (2017). Disengaged parenting: Structural equation modeling with child abuse, insecure attachment, and adult symptomatology. Child Abuse \& Neglect, 67, 260-270. doi:10.1016/J.CHIABU.2017.02.036

Cardoso, L. M., Gomes, G. V. A., \& Vieira, T. S. (2018). Validity evidence of the Zulliger-SC Test to children's assessment. Psico-USF, 23(3), 451-460. doi:10.1590/1413-82712018230305

Casali-Robalinho, I. G., Del Prette, Z. A. P., \& Del Prette, A. (2015). Habilidades sociais como preditoras de problemas de comportamento em escolares [Social skills as predictors of problem behavior in school children]. Psicologia: Teoria e Pesquisa, 31(3), 321-330. doi:10.1590/0102-37722015032110321330

Cicchetti, D. V. (1994). Guidelines, criteria, and rules of thumb for evaluating normed and standardized assessment instruments in psychology. Psychological Assessment, 6(4), 284-290. doi:10.1037/1040-3590.6.4.284

De Michèle, S., Kabuth, B., Plun, O., Le Moal, L., Laurent, F., Vandelet, E., ... De Tychey, C. (2019). Rorschach Trauma Content Index (TCI) and child sexual abuse diagnostic. Annales Medico-Psychologiques, Revue Psychiatrique, 177(6), 512-516. doi:10.1016/j.amp.2018.03.002

Del Prette, Z. A. P. (2017). Inventário de habilidades sociais, problemas de comportamento e competência acadêmica para crianças [Inventory of social skills, behavioral problems and academic competence for children]. São Paulo, SP: Pearson Clinical Brasil. 
Exner, J. E., Jr. (1999). Manual de classificação do Rorschach para o sistema compreensivo [The Rorschach: A comprehensive system] (A. C. P. Silva Neto, Trans.). São Paulo, SP: Casa do Psicólogo.

Exner, J. E., Jr., \& Sendín, C. (1999). Rorschach: Manual de interpretação para o sistema comprensivo [Rorschach: Interpretation manual] (L. Y. Massuh, Trans.). São Paulo, SP: Casa do Psicólogo.

Eysenck, H. J., \& Eysenck, S. B. G. (2013). Questionário de Personalidade para Crianças e Adolescentes (EPQ-J) [Manual of the Eysenck Personality Questionnaire Junior] (C. G. Schlottfeldt, Trans.) São Paulo, SP: Vetor.

Gabatz, R. I. B., Schwartz, E., Milbrath, V. M., Zillmer, J. G. V., \& Neves, E. T. (2017). Teoria do apego, interacionismo simbólico e teoria fundamentada nos dados: Articulando referenciais para a pesquisa [Attachment theory, symbolic interactionism and grounded theory: Articulationg reference frameworks for research]. Texto \& Contexto - Enfermagem, 26(4), e1940017. doi:10.1590/0104-07072017001940017

Goggin, E. L., Lansky, S. B., \& Hassanein, K. (1976). Psychological reactions of children with malignancies. Journal of the American Academy of Child Psychiatry, 15(2), 314-325. doi:10.1016/S0002-7138(09)61490-4

Habigzang, L. F., \& Koller, S. H. (2011). Intervenção psicológica para crianças e adolescentes vítimas de violência sexual: Manual de capacitação profissional [Psychological intervention for children and adolescents victims of sexual violence: Professional training manual]. São Paulo, SP: Casa do Psicólogo.

Lewey, J. H., Kivisalu, T. M., \& Giromini, L. (2019). Coding with R-PAS: Does prior training with the exner comprehensive system impact interrater reliability compared to those examiners with only R-PAS-based training? Journal of Personality Assessment, 101(4), 393-401. doi:10.1080/00223891.2018.1476361

Meyer, G. J., Viglione, D. J., Mihura, J. L., Erard, R. E., \& Erdberg, P. (2017). Rorschach sistema de avaliação por desempenho manual de aplicação, codificação e interpretação e manual técnico [Rorschach performance evaluation system, application, coding and interpretation and technical manual] (F. K. Miguel \& D. R. Silva, Trans.). São Paulo, SP: Hogrefe.

Ministério da Saúde. Secretaria de Vigilância em Saúde. (2018). Análise epidemiológica da violência sexual contra crianças e adolescentes no Brasil, 2011 a 2017 [Epidemiological analysis of sexual violence against children and adolescents in Brazil, 2011 to 2017]. Boletim Epidemiológico, 49(27), 1-17. Retrieved from https://portaldeboaspraticas.iff.fiocruz. br/wp-content/uploads/2019/07/2018-024.pdf
Perfect, M. M., Tharinger, D. J., Keith, T. Z., \& Lyle-Lahroud, T. (2011). Relations between Minnesota Multiphasic Personality Inventory-A scales and Rorschach variables with the scope and severity of maltreatment among adolescents. Journal of Personality Assessment, 93(6), 582-591. doi:10.1080/00223891.2011.608754

Santos, M. J., Mascarenhas, M. D. M., Malta, D. C., Lima, C. M., \& Silva, M. M. A. (2019). Prevalência de violência sexual e fatores associados entre estudantes do ensino fundamental - Brasil, 2015 [Prevalence of sexual violence and associated factors among primary school students Brazil, 2015]. Ciência \& Saúde Coletiva, 24(2), 535-544. doi:10.1590/1413-81232018242.13112017

Schaefer, L. S., Brunnet, A. E., Lobo, B. O. M., Carvalho, J. C. N., \& Kristensen, C. H. (2018). Indicadores psicológicos e comportamentais na perícia do abuso sexual infantil [Psychological and behavioral indicators in the forensic assessment of child sexual abuse]. Temas em Psicologia, 26(3), 1467-1482. doi:10.9788/TP2018.3-12Pt

Scortegagna, S. A., Ribeiro, R. K. S. M., \& Villemor-Amaral, A. E. (2016). New contributions of the Rorschach method on the effects of sexual abuse in childhood. Psychology, 7(2), 215-222. doi:10.4236/psych.2016.72024

Scortegagna, S. A., \& Villemor-Amaral, A. E. (2012). The use of the Rorschach method in the investigation of sexual abuse of children. Paidéia (Ribeirão Preto), 22(52), 271-280. doi:10.1590/S0103-863X2012000200013

Scortegagna, S. A., \& Villemor-Amaral, A. E. (2013). Traumatic loss and helplessness: Qualitative analysis of responses in the Rorschach. Psico-USF, 18(1), 1-12. doi:10.1590/S1413-82712013000100002

Seitl, M., Dočkalová, J., Dostál, D., Kolařík, M., Hasoňová, V., Palová, K., \& Fryštacká, K. (2018). Standardizace počtu odpovědí v zulligerově testu: První krok při vývoji nového evidence - based systému [The standardization of the number of responses in Zulliger test: The first step towards developing a new evidence-based system]. E-Psychologie, 12(4), 1-15. doi:10.29364/epsy.328

Signorelli, S. C. (2015). Cancer and Rorschach from an existential perspective. Existential Analysis, 26(1), 70-85.

Simões, N. C., \& Castro, P. F. (2018). Avaliação psicológica em escolares: Relação entre personalidade, autoconceito e habilidades sociais [Psychological assessment in students: Relationship between personality, self-concept and social skills]. Gerais: Revista Interinstitucional de Psicologia, 11(1), 26-44. doi:10.36298/gerais2019110104

Sisto, F. F. (2004). Escala de Traços de Personalidade para crianças. São Paulo, SP: Vetor.

Villemor-Amaral, A. E., Pavan, P. M. P., Tavella, R. R., Cardoso, L. M., \& Biasi, F. C. (2016). Validity evidence of the Z-test-SC for use with children. Paidéia (Ribeirão Preto), 26(64), 199-206. doi:10.1590/ $1982-43272664201607$ 
Villemor-Amaral, A. E., \& Primi, R. (2009). Z-SC: Teste de Zulliger no sistema compreensivo - Forma individual [Z-SC system: Zulliger test in the comprehensive Individual form]. São Paulo, SP: Casa do Psicólogo.

Villemor-Amaral, A. E., \& Vieira, P. G. (2016). Zulliger (CS) in assessing the relational maturity of children. Paidéia (Ribeirão Preto), 26(65), 369-376. doi:10.1590/ $1982-43272665201601$

Wu, Q., Chi, P., Lin, X., \& Du, H. (2018). Child maltreatment and adult depressive symptoms: Roles of self-compassion and gratitude. Child Abuse \& Neglect, 80, 62-69. doi:10.1016/j.chiabu.2018.03.013

Yamamoto, K., Kanbara, K., Mutsuura, H., Ban, I., Mizuno, Y., Abe, T., ... Fukunaga, M. (2010). Psychological characteristics of Japanese patients with chronic pain assessed by the Rorschach test. BioPsychoSocial Medicine, 4, 20. doi:10.1186/1751-0759-4-20

Eduardo dos Santos de Lima has a Master's degree from the Graduate Program in Human Aging from Universidade de Passo Fundo, Passo Fundo-RS, Brazil.

Silvana Alba Scortegagna is a Professor at Universidade de Passo Fundo, Passo Fundo-RS, Brazil.

Ana Carolina Bertoletti De Marchi is a Professor at Universidade de Passo Fundo, Passo Fundo-RS, Brazil.

Authors' Contribution:

All authors have made substantial contributions to the conception and design of this study, to data analysis and interpretation, to manuscript revision and approval of the final version. All the authors assume public responsibility for manuscript's content.

Associate editor:

Vanessa Barbosa Romera Leme

Received: May. 29, 2020

1st Revision: Nov. 25, 2020

2nd Revision: Dec. 16, 2020

Approved: Jan. 04, 2021

How to cite this article:

Lima, E. S., Scortegagna, S. A., \& De Marchi, A. C. B. (2021). Zulliger R-Optimized application in children victims of sexual violence and cancer. Paidéia (Ribeirão Preto), 31, e3115.doi:https://doi.org/10.1590/1982-4327e3115 